December 16, 2011

\title{
Cross-Border Shareholder Class Actions Before and After Morrison
}

\author{
Working Paper
}

\author{
Elaine Buckberg, Ph.D \\ Max Gulker, Ph.D
}

NERA

Economic Consulting

This working paper is distributed for purposes of comment and discussion only. It may not be reproduced without permission of the copyright holder. The opinions expressed herein do not necessarily represent the views of NERA Economic Consulting or any other NERA consultant. 


\title{
Cross-Border Shareholder Class Actions Before and After Morrison
}

\author{
by
}

\author{
Elaine Buckberg and Max Gulker*
}

\begin{abstract}
We conduct an empirical inquiry into the effect of the Supreme Court's 2010 Morrison decision, which limited the reach of US securities laws to trades occurring on US markets, on the competitiveness of US markets as a venue for listings by foreign issuers and trading in cross-listed stocks. In the wake of the Morrison decision, the Dodd-Frank Act requires that the SEC inform Congress about the merits of creating a new extraterritorial right of action. We provide input into the debate by using data on 329 shareholder class actions filed against foreign-domiciled companies and discussing the effects of such a right on the competitiveness of U.S. capital markets. We conclude that, following Morrison, foreign companies' expected litigation costs should fall, because investors who purchased their shares on overseas exchanges will be excluded from classes. By reducing expected litigation costs, Morrison eases a deterrent to US listing by foreign issuers and thereby makers the US a more competitive venue for crosslistings, as well as for the volume in cross-listed stocks.
\end{abstract}

First Version: October 27, 2011.

This Version: December 16, 2011.

Key words: Multi-market trading; Cross-listed stocks; Regulatory change.

JEL Classification Codes: F30, G32, G15.

\footnotetext{
* Elaine Buckberg is Senior Vice President and Max Gulker is Senior Consultant at NERA Economic Consulting. The authors thank Chyhe Becker, Timothy Helwick, Daniel Kramer, David Tabak and participants in a seminar at the Securities and Exchange Commission for insightful comments; Svetlana Starykh for assistance with NERA's Class Action Database; and Gary Wu, Tyler Wood and Grace Kaminer for superb research assistance. All errors, omissions and other issues are the authors' alone.
} 


\section{Introduction}

Congress will soon consider whether to legislate an extraterritorial private right of action under Section 10(b) of the Securities Exchange Act of 1934 ("Exchange Act") that US courts had recognized for decades. In June 2010, the Supreme Court ruled in Morrison v. National Australia Bank that only trades on US markets are covered under the Exchange Act. ${ }^{1}$ For decades, US courts had heard securities cases under Section 10(b) against foreign issuers, beginning with Schoenbaum v. Firstbrook in $1968 .^{2}$ Courts had defined tests to determine which purchases would be covered based on whether the investors were American, whether they bought their shares on US markets, and whether and which fraudulent acts had occurred in the US. The Supreme Court nullified these tests on grounds that no US law applies outside the US borders unless the law gives a clear indication that it is intended to apply extraterritorially. ${ }^{3}$ In the Dodd-Frank Wall Street Reform and Consumer Protection Act ("Dodd-Frank"), Congress took two actions partially reversing the impact of the Morrison decision via legislation. Congress immediately restored the ability of the government and the Securities and Exchange Commission (“SEC”) to bring cases under Section 10(b) involving transnational securities fraud. In addition, Congress directed the SEC to study the merits of creating a new extraterritorial private right of action.

1 Morrison v. National Australia Bank Ltd., 130 S. Ct. 2869, 2884 (2010).

2 Buxbaum, Hannah, "Multinational Class Actions Under Federal Securities Law: Managing Jurisdictional Conflict," Columbia Journal of Transnational Law, Volume 46, Issue 1, June 2007, p. 21.

3 Morrison v. National Australia Bank Ltd., 130 S. Ct. 2878 (2010). 
This paper provides input into the debate on the merits of creating a new private right of action by reviewing the 329 shareholder class actions filed against foreign-domiciled companies and discussing the effects of such a right on the competitiveness of US capital markets. We focus on Rule 10b-5 shareholder class actions against foreign issuers, which we define to involve suits against a foreign issuer whose stock trades on US markets, on behalf of a plaintiff class that includes both investors who purchased their securities on US markets and investors who purchased their securities overseas. ${ }^{4,5}$ We conclude that, following Morrison, foreign companies' expected litigation costs should fall, because investors who purchased their shares on overseas exchanges will be excluded from classes, driving down damages and settlements. By reducing expected litigation costs, Morrison eases a deterrent to US listing by foreign issuers and thereby makes the US a more competitive venue for cross-listings, as well as for the volume in cross-listed stocks.

\section{Filings Against Non-US Companies in US Courts}

US courts have been an attractive venue for plaintiffs to file shareholder class actions, even against companies domiciled in foreign countries. Although other countries have recently

4 Since PSLRA, all Rule 10b-5 securities class actions brought against foreign issuers involved stocks that traded on US markets, whether on an exchange or over the counter ("OTC"); many of these stocks also traded overseas, in some cases with the overwhelming majority of the volume trading outside the US. NERA Securities Class Action Database.

5 The Morrison decision describes broad acceptance that the Exchange Act applied only to stocks traded on US exchanges: "The primacy of the domestic exchange is suggested by the very prologue of the Exchange Act, which sets forth as its object " $[\mathrm{t}$ ] p provide for the regulation of securities exchanges ... operating in interstate and foreign commerce and through the mails, to prevent inequitable and unfair practices on such exchanges ... .' 48 Stat. 881. We know of no one who thought that the Act was intended to 'regulat[e]' foreign securities exchanges - or indeed who even believed that under established principles of international law Congress had the power to do so. The Act's registration requirements apply only to securities listed on national securities exchanges. 15 U. S. C. §781(a).” Morrison v. National Australia Bank Ltd., 130 S. Ct. 2874 (2010). 
created a legal framework for class action litigation, including Australia, Canada and Italy, long standing and well-defined class action rules in the US make it a uniquely well-suited venue for this type of litigation. ${ }^{6}$ Participating in a class action is essentially a free call option to plaintiffs, removing any downside financial risk as well as the need for plaintiffs to coordinate to fund litigation. US law allows for contingency fee arrangements, where plaintiffs' attorneys fund the litigation and receive a percentage of any damages or settlement. Furthermore, the US does not have the fee-shifting rules common in other countries that require the losing side to pay some or all of the winner's legal fees. As a result, plaintiffs incur no legal expenses to enter litigation and minimal, if any, financial risk. Lead plaintiffs will invest only time in participating and supervising litigation, and there is no cost whatsoever to other class members. Finally, the jury trial system in the US increases the probability of large verdicts against defendant corporations, should cases go to trial. ${ }^{7}$

For these reasons, plaintiffs and their attorneys have substantial incentives to file shareholder class actions in the US. Without restrictions on access to US courts, suits might be filed in response to disclosure of fraud against companies from around the world, even without a US listing, provided they involved substantial market capitalization, a large price drop, and good record keeping of stock ownership.

Plaintiffs have regularly filed shareholder class actions against non-US companies in US courts, and the rate of filing shows no sign of declining subsequent to the Morrison decision in

6 Gassman, Gary and Perry Granof, "Global Issues Affecting Securities Claims at the Beginning of the TwentyFirst Century,” Tort Trial \& Insurance Practice Law Journal, Fall 2007 (43:1), pp. 85-111.

7 Grant, Stuart and Diane Zilka, "The Role of Foreign Investors in Federal Securities Class Actions," Securities Litigation and Enforcement Institute 2004, Corporate Law and Practice, Course Handbook Series Number B1442. 
2010. Figure 1 reports filings against non-US companies by year, from 1996 through June 2011. While the number of filings has fluctuated from year to year, at least 19 actions have been filed against non-US companies in every year since 2007. The dramatic increase in filings in 2011 is primarily driven by a wave of actions filed against Chinese companies. Of 40 actions against non-US companies filed in the first half of 2011, 27 were against Chinese companies, all of which listed their stock only in the US. However, even excluding these cases, it is clear that filings against foreign companies have not decreased since the Morrison decision in June 2010.

Figure 1

Shareholder Class Actions Against Non-US Companies Filed in US Courts ${ }^{1}$ January 1996 - June 2011

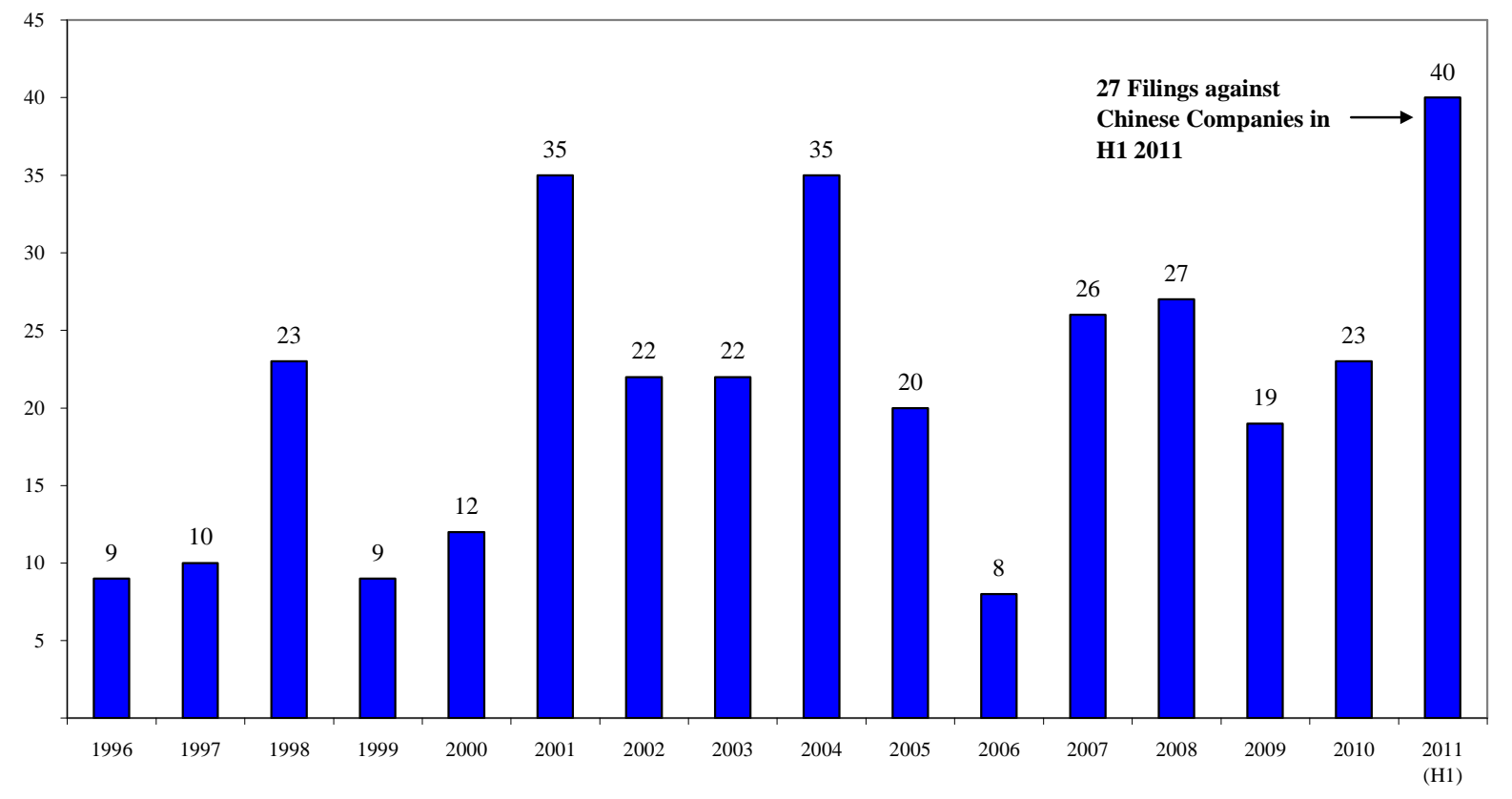

${ }^{1}$ Excludes filings against defendants domiciled in Caribbean tax havens.

Historically, companies domiciled in Europe and Canada have accounted for the majority of filings against non-US companies. Figure 2 reports annual filings by the defendant company's 
country or region. Prior to 2010, companies domiciled in Europe and Canada accounted for at least $50 \%$ of all filings against non-US companies: Canadian firms faced more filings than those from any other country until 2007. While filings against Chinese companies have increased since 2010, filings against European and Canadian firms have remained within historical ranges.

Figure 2

Shareholder Class Actions Against Non-US Companies Filed in US Courts by Company Domicile ${ }^{1}$ January 1996 - June 2011

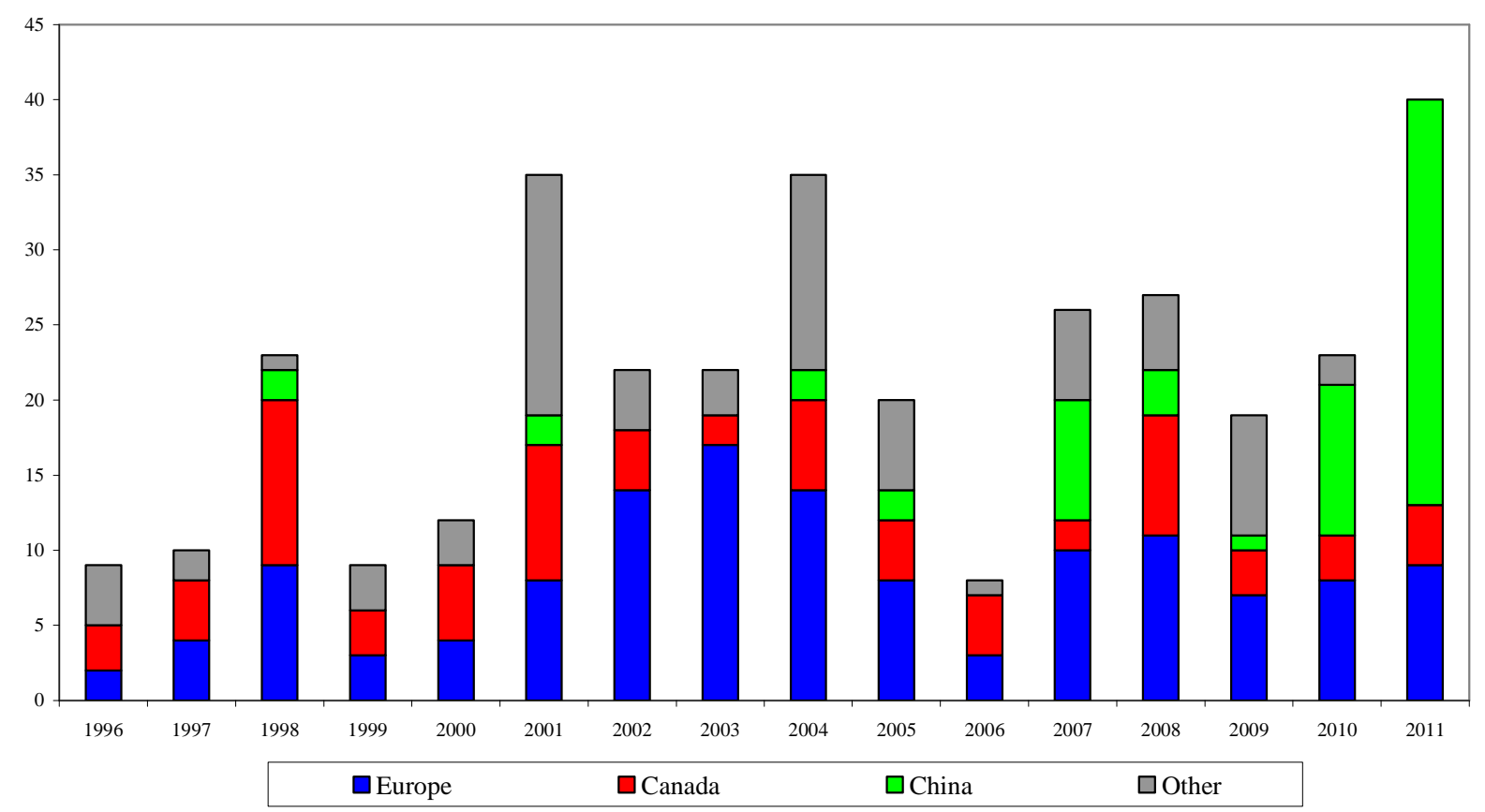

${ }^{1}$ Excludes filings against defendants domiciled in Caribbean tax havens.

In most years since 1996, foreign companies listing in the US have faced lower odds of a shareholder class action than domestic companies. As Figure 3 shows, in all but four years, foreign companies accounted for a greater percentage of US listings than class action filings. The greatest outlier, by far, is the first half of 2011, which is driven primarily by the large 
number of suits against Chinese firms filed this year. Excluding these 27 filings, foreign firms would account for $13.1 \%$ of filings in the first half of 2011.

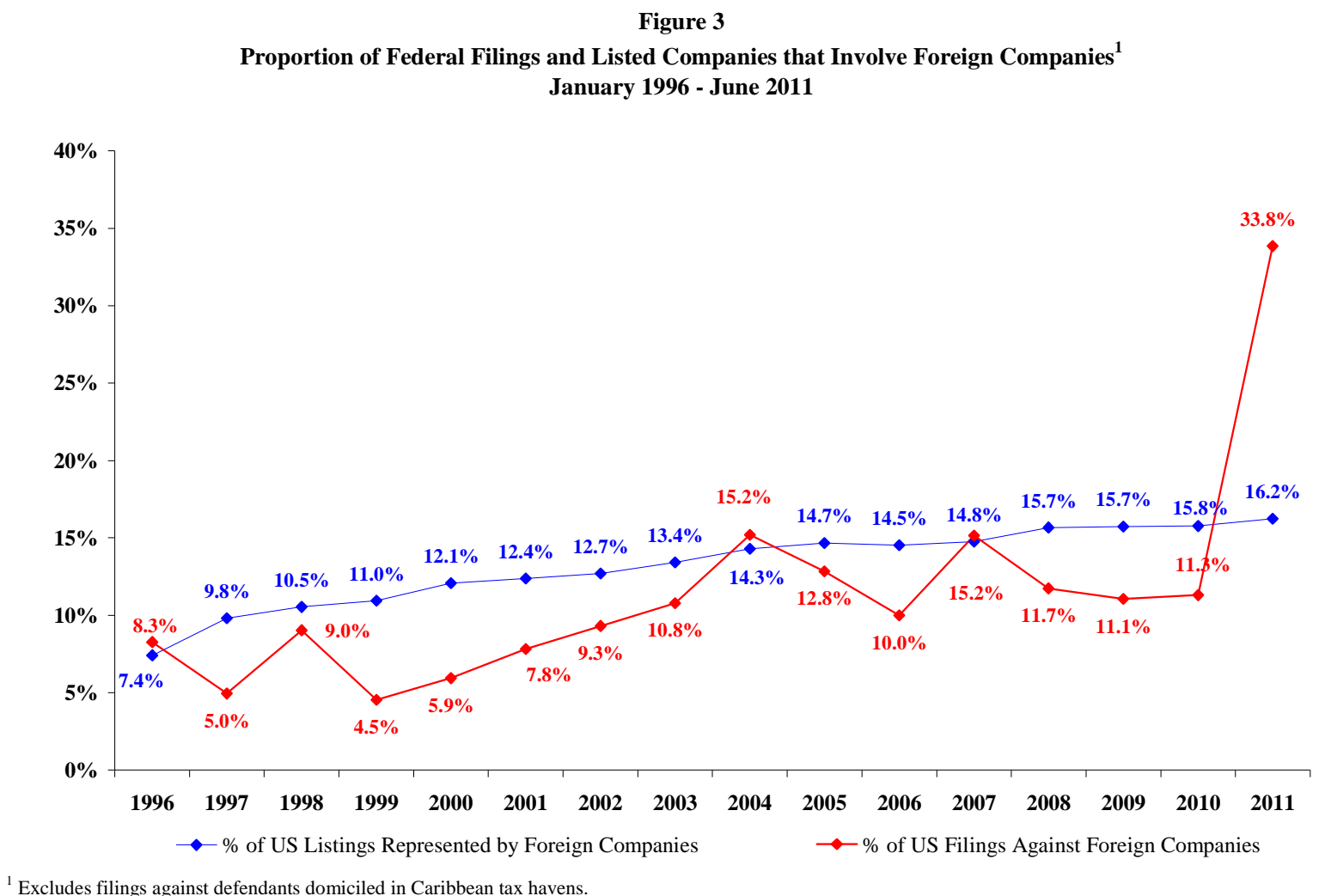

\section{Inclusion of $\mathbf{F}^{3}$ Investors}

Prior to the Supreme Court's decision in Morrison, courts ruled on a case-by-case basis on

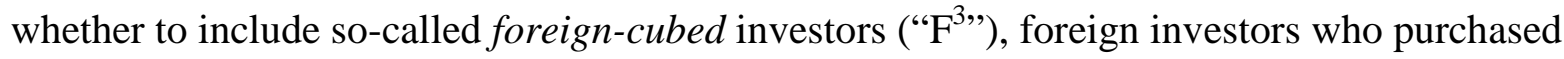
shares of a foreign-domiciled company on a foreign market, in a class. These rulings followed a common framework, in which courts could decide whether to exclude $\mathrm{F}^{3}$ investors at two separate stages of the litigation. First, courts determined whether they had subject matter jurisdiction over trades made by $\mathrm{F}^{3}$ investors. Through a series of decisions, the courts had articulated two tests, the conduct test and the effects test, that were required to be satisfied to 
create jurisdiction. Second, $\mathrm{F}^{3}$ investors could be excluded at the class certification stage, where the primary issue was whether courts in foreign plaintiffs' home countries would hear litigation of the same claims following a US resolution. ${ }^{8}$

This section begins by discussing the number of cases filed against non-US companies in which $\mathrm{F}^{3}$ investors were included in the initial class. Next, we discuss courts' standards for determining whether subject matter jurisdiction exists over trades made by $\mathrm{F}^{3}$ investors, and report statistics on the number of instances where $\mathrm{F}^{3}$ investors have been allowed or excluded based on these tests. Finally, we discuss class certification, and provide statistics on $\mathrm{F}^{3}$ investors' inclusion or exclusion at this stage of litigation.

\section{A. Filings Including $\mathbf{F}^{3}$ investors}

Not all shareholder class actions against non-US companies involve $\mathrm{F}^{3}$ investors. First, some defendant companies trade only in US markets, and therefore do not involve investors purchasing in foreign markets. Second, even in some cases where defendant companies are traded on multiple markets, plaintiffs choose to file actions solely on behalf of investors purchasing shares or ADRs on US markets.

Figure 4 reports filings by year against defendant companies traded on multiple markets and those traded only in the US. Of 340 total filings, 147 (43\%) were against companies listed on both US and foreign exchanges. All 27 Chinese firms that were defendants in actions filed in the first half of 2011 traded only on US markets, causing the proportion of dual-listed firms in 2011 to be below that of previous years. All 27 Chinese companies had listed via reverse

8 Bersch v. Drexel Firestone, Inc., 519 F.2d 974, 996 (2d Cir. 1975). 
mergers, enabling them to avoid the level of regulatory scrutiny required for an IPO; the subsequent class actions all raise accounting allegations.

Figure 4

Trading Location of Shareholder Class Actions Against Non-US Companies ${ }^{1}$

January 1996 - June 2011

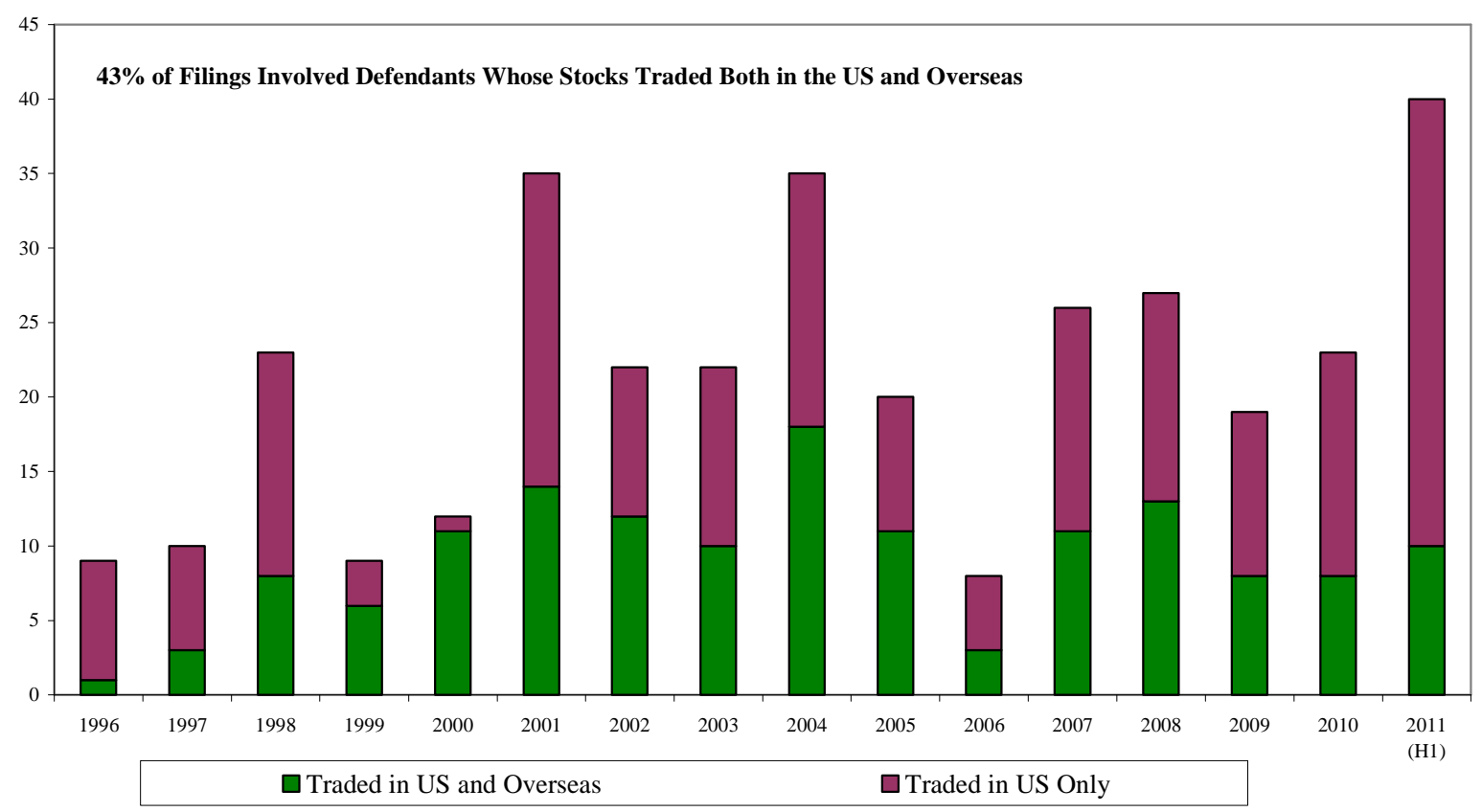

${ }^{1}$ Excludes filings against defendants domiciled in Caribbean tax havens.

Figure 5 reports the number of filings against those companies traded on multiple markets, and whether plaintiffs filed on behalf of all investors (including purchasers on foreign exchanges) or only US investors. Of 147 total filings against dual-listed defendants, 107 (73\%) included purchasers on all exchanges (and therefore $\mathrm{F}^{3}$ investors) in the proposed class in the complaint. 
Figure 5

Inclusion of $\mathbf{F}^{3}$ Investors in Shareholder Class Actions Against Non-US Companies ${ }^{1}$

January 1996 - June 2011

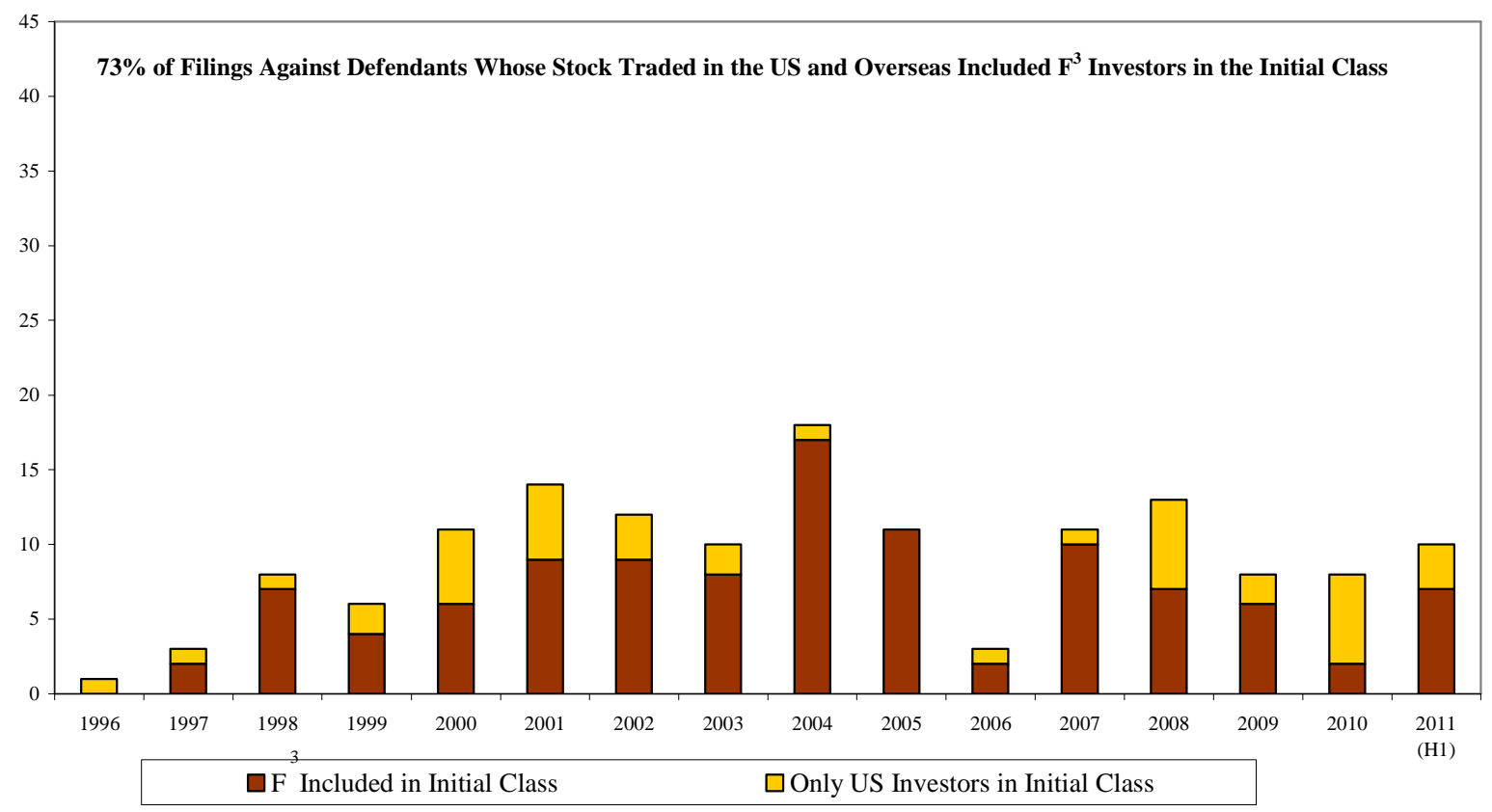

${ }^{1}$ Excludes filings against defendants domiciled in Caribbean tax havens.

\section{B. Subject Matter Jurisdiction}

Prior to Morrison, courts decided whether subject matter jurisdiction existed over trades by $\mathrm{F}^{3}$ investors on a case-by-case basis. Decisions on subject matter jurisdiction were based on the application of two tests, the conduct test and the effects test, and satisfaction of either test resulted in a finding of subject matter jurisdiction over the trades of a given class of plaintiffs.

The diagram below shows the typical pre-Morrison framework for subject matter jurisdiction over trades by investors in a foreign firm. As explained in more detail below, investors satisfied the effects test if they were either residents of the US, or purchased on a US market. Because they were neither residents nor purchased in the US, $\mathrm{F}^{3}$ investors did not satisfy the 
effects test, and decisions regarding subject matter jurisdiction were made on a case-by-case basis based on the conduct test.

Figure 6

\section{Pre-Morrison Subject Matter Jurisdiction Investors in a Foreign Firm}

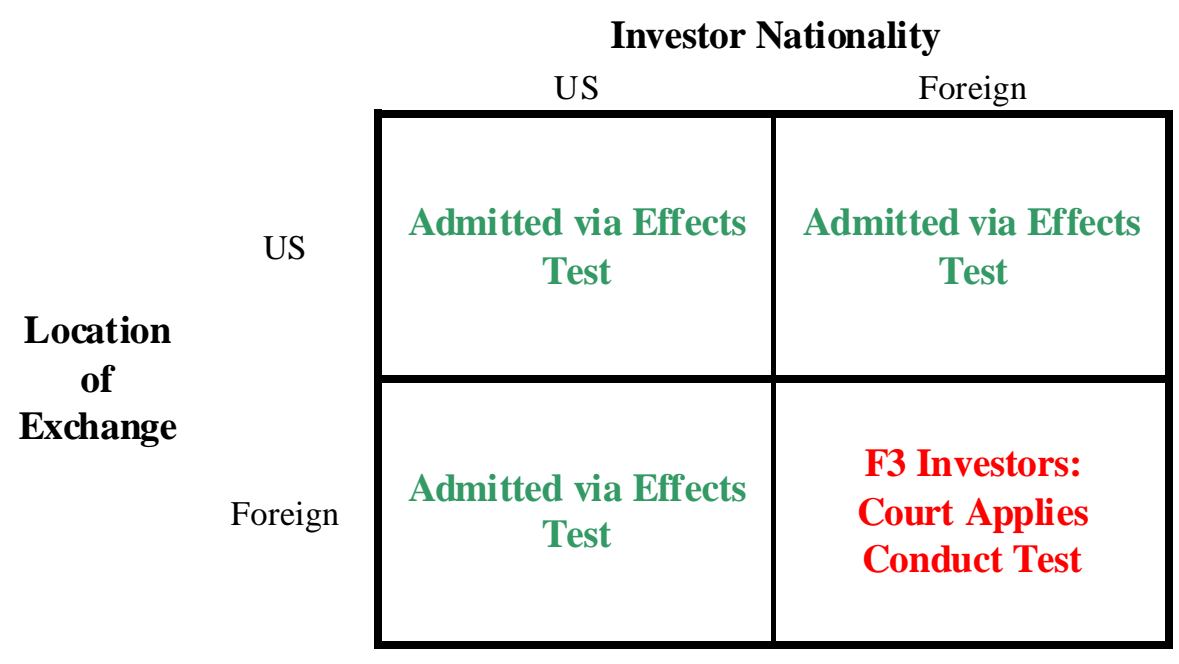

Satisfaction of the effects test depends on whether the defendant's allegedly fraudulent conduct directly affected US investors or markets. The test was first articulated in Schoenbaum v. Firstbrook (1968), an action brought against a Canadian corporation by a US shareholder. ${ }^{9}$ The court found that,

Congress intended the Exchange Act to have extraterritorial application in order to protect domestic investors who have purchased foreign securities on American exchanges and to

9 Buxbaum, Hannah, "Multinational Class Actions Under Federal Securities Law: Managing Jurisdictional Conflict," Columbia Journal of Transnational Law, Volume 46, Issue 1, June 2007, p. 21. 
protect the domestic securities market from the effects of improper foreign transactions in American securities. ${ }^{10}$

Courts typically found that investors living in the US, or purchasing shares on US markets, therefore satisfied the effects test, while finding that $\mathrm{F}^{3}$ investors failed to meet its requirements. ${ }^{11}$

Courts therefore turned to the conduct test to establish the extent of subject matter jurisdiction over $\mathrm{F}^{3}$ investors. ${ }^{12}$ Satisfaction of the conduct test depends on whether the alleged fraudulent conduct took place within the US. The test was first articulated in Leasco v. Maxwell, in which the Second Circuit found that the test was satisfied in the case of fraud committed in the US that induced a US investor to purchase securities in London. ${ }^{13}$ However, in IIT v. Vencap, Ltd. (1975), the Second Circuit found that the conduct test was satisfied even if investors were not based in the US, stating, "[W]e do not think Congress intended to allow the United States to be used as a base for manufacturing fraudulent security devices for export, even when these are peddled only to foreigners." 14

As the conduct test evolved, different circuits developed notably different standards for when the conduct test was satisfied. The D.C. Circuit has adopted the most stringent standard, finding that the test was satisfied only if all factors required by Section 10(b) of the Securities

10 Schoenbaum v. Firstbrook 405 F.2d 215 (2d. Cir. 1968) at 206.

11 Buxbaum, Hannah, "Multinational Class Actions Under Federal Securities Law: Managing Jurisdictional Conflict," Columbia Journal of Transnational Law, Volume 46, Issue 1, June 2007, pp. 42-3.

12 Id. at 43.

13 Id. at 23.

14 IIT v. Vencap, Ltd., 519 F.2d 1001, 1017 (2d Cir. 1975) 
and Exchange Act were committed in the US. ${ }^{15}$ In contrast, the Second, Fifth and Seventh Circuits required that acts "more than merely preparatory conduct to the fraud" took place in the US and that the US conduct caused the foreign plaintiffs' loss. ${ }^{16}$ The Third, Eighth and Ninth Circuits adopted the least stringent standard, requiring only that some conduct designed to further the fraudulent scheme occurred in the US. ${ }^{17}$

Figure 6 reports the number of instances, both overall and by region, in which US courts found subject matter jurisdiction over $\mathrm{F}^{3}$ investors. Of 107 filings including $\mathrm{F}^{3}$ investors in the initial class, 41 reached a point where the court decided on subject matter jurisdiction over trading by $\mathrm{F}^{3}$ investors. ${ }^{18}$ In 27 of 41 cases $(66 \%)$, courts found that subject matter jurisdiction existed over $\mathrm{F}^{3}$ investors' trades. Courts were more likely to find subject matter jurisdiction over trading by $\mathrm{F}^{3}$ investors in cases involving Canadian defendant firms, with findings favorable to $\mathrm{F}^{3}$ plaintiffs in 15 of 19 cases $(79 \%)$ versus 9 of 18 cases $(50 \%)$ for defendants domiciled in Europe.

15 Grant, Stuart and Diane Zilka, "The Role of Foreign Investors in Federal Securities Class Actions," Securities Litigation and Enforcement Institute 2004, Corporate Law and Practice, Course Handbook Series Number B1442, p. 6.

16 Id.

17 Id.

18 The majority of cases were either settled or dismissed before this phase, or remain pending. 
Figure 7

$F^{3}$ Subject Matter Jurisdiction

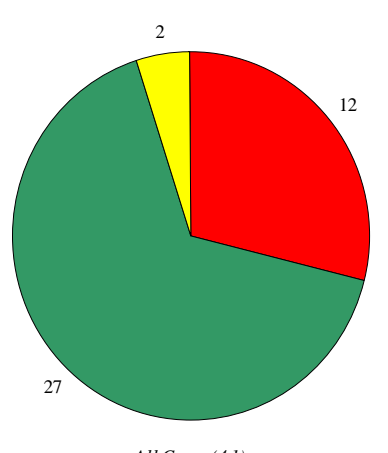

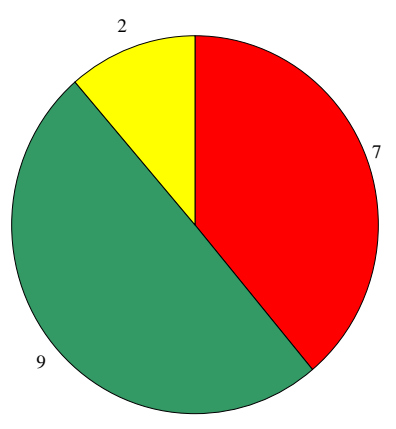

Europe (18)

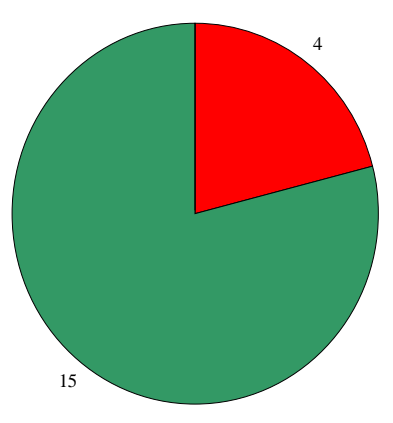

Canada (19)

Fin ding of SMJ: $\mathrm{F}^{3}$ Allowed

No SMJ: $F^{3}$ Dismissed

SMJ Over Some Claims: Some $\mathrm{F}^{3}$ Allowed

\section{Class Certification}

Beyond the normal class certification issues, the certification of classes including $\mathrm{F}^{3}$ investors depends primarily on whether courts in foreign plaintiffs' home countries would hear litigation of the same claims following a US resolution. Courts historically excluded $\mathrm{F}^{3}$ investors from classes when they found that there was a "near certainty" that courts in plaintiffs' home countries would fail to recognize a judgment or settlement in US courts, with the "near certainty" standard first articulated in Bersch (1975). ${ }^{19}$ In a 2007 decision in Vivendi, however,

19 American Bar Association, "Securities Class Actions in a Global Economy: Investor Claims Against Non-US Issuers," 2007, p. 10. 
the Southern District of New York revisited the standard put forward in Bersch, and found instead that $\mathrm{F}^{3}$ investors should be excluded if it is "more likely than not" that the relevant foreign court would fail to recognize the US outcome. ${ }^{20}$ The Vivendi court evaluated the claims of $\mathrm{F}^{3}$ investors on a country-by-country basis, allowing investors from England, the Netherlands and France to remain in the class, while excluding investors from Germany and Austria.

Figure 7 reports the number of instances, both overall and by region, in which US courts certified classes including $\mathrm{F}^{3}$ investors. Of 107 filings including $\mathrm{F}^{3}$ investors in the initial class, 38 reached a point where the court ruled on class certification. ${ }^{21}$ In 23 of 38 cases (61\%), courts included $\mathrm{F}^{3}$ investors in the certified class. Courts were more likely to certify $\mathrm{F}^{3}$ investors as class members in cases involving Canadian defendant firms, with findings favorable to $\mathrm{F}^{3}$ plaintiffs in 17 of 22 cases (77\%) versus 6 of 13 cases (46\%) for defendants domiciled in Europe.

20 Id. at 13.

21 The majority of cases were either settled or dismissed before this phase, or remain pending. 

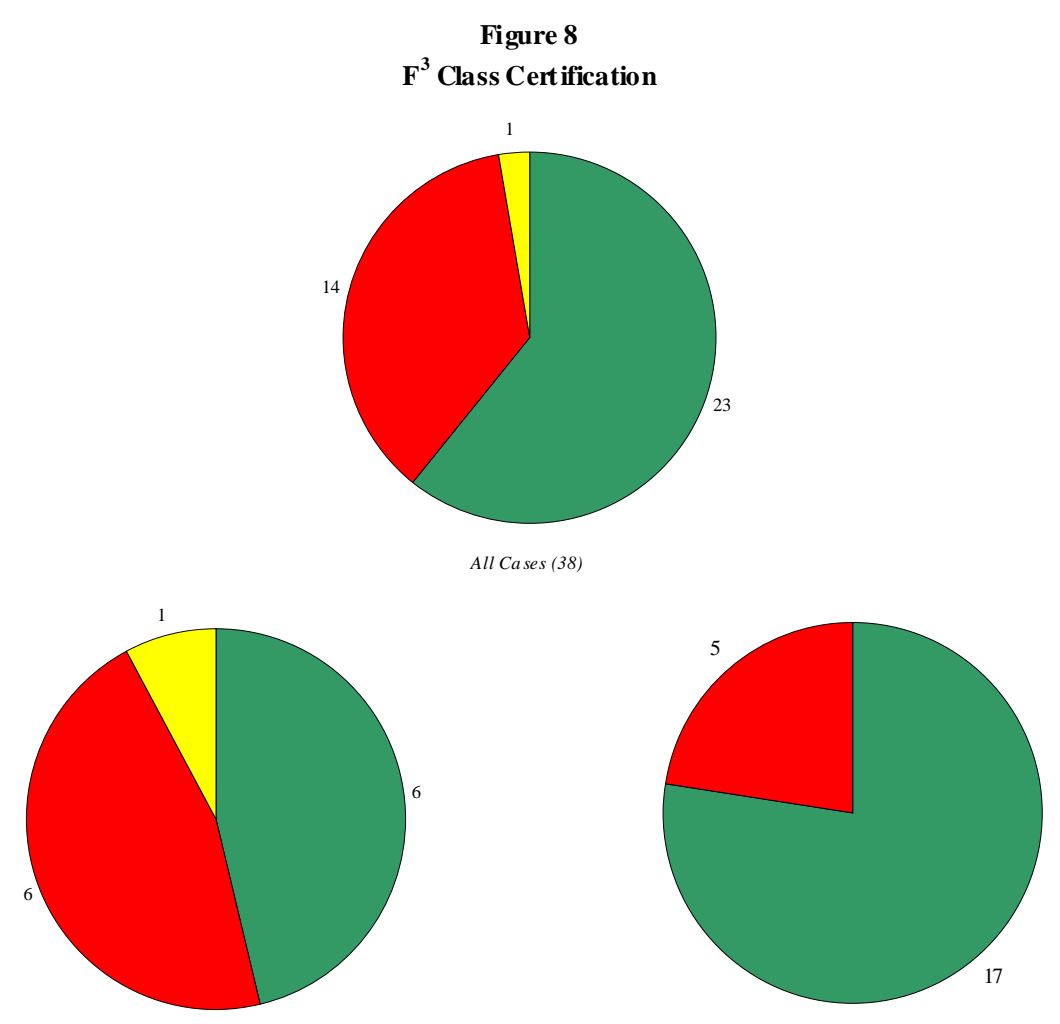

Europe (13)

Canada (22)

$\square$ F $^{3}$ Certified $\square$ F $^{3}$ Not Certified $\square$ F $^{3}$ Certified In Part

\section{Morrison v. National Australia Bank}

Morrison v. National Australia Bank (NAB) rose to a Supreme Court appeal in part because, by the appeal, all three lead plaintiffs were $\mathrm{F}^{3}$ investors. NAB shares trade in Australia, New Zealand, London and Tokyo, while its ADRs trade in the US. NAB's US subsidiary HomeSide Lending overstated the value of its mortgage servicing rights from 1998 through 2001, causing NAB to restate its financials for those years. ${ }^{22}$ After Judge Barbara Jones in the Southern District of New York rejected subject matter jurisdiction, plaintiffs appealed to the Second

22 Morrison.at 2875. 
Circuit, which affirmed the District Court decision on grounds that the actions by NAB in Australia, where the company's SEC filings were prepared, were more central to the fraud. ${ }^{23}$

However, the Second Circuit declined to make a bright line rule that conduct alone is insufficient to satisfy $\mathrm{F}^{3}$ subject matter jurisdiction, citing the importance of preventing the export of fraud from the US. It instead highlighted whether the US conduct was "the heart of the alleged fraud." 24 In the Supreme Court phase, amicus briefs proposed new standards. The US Chamber of Commerce proposed that the Court rule that trades by $\mathrm{F}^{3}$ plaintiffs be excluded from jurisdiction, ${ }^{25}$ while the US Solicitor General and the SEC jointly proposed that jurisdiction include trades by $\mathrm{F}^{3}$ investors if the conduct in the US “is material to the fraud's success and forms a substantial component of the fraudulent scheme."26

Rather than excluding $\mathrm{F}^{3}$ purchases, the Supreme Court excluded all purchases not made in the US, stating that the discussion of jurisdiction was misplaced, and that the only question was what the statute covers. The majority opinion stated,

[T]he focus of the Exchange Act is not upon the place where the deception originated, but upon purchases and sales of securities in the United States. Section 10(b) does not punish deceptive conduct, but only deceptive conduct 'in connection with the purchase or sale of any security

23 Morrison v. National Australia Bank Ltd., 547 F. 3d 167, 175 (2d Cir. 2008).

24 Morrison (2d Cir.)

25 Brief of Amici Curiae the Securities Industry and Financial Markets Association et al. in Support of Respondents at 4, Morrison v. National Australia Bank Ltd., 130 S. Ct. 2869 (2010) (No. 08-1191).

26 Brief for the United States as Amicus Curiae at 13, Morrison v. National Australia Bank Ltd., 130 S. Ct. 2869 (2010) (No. 08-1191). 
registered on a national securities exchange or any security not so registered.' 15 U.S. C. $\$ 78 j(b){ }^{27}$

Although the Morrison case itself dealt only with $\mathrm{F}^{3}$ investors, Justice Stevens, in his dissent, raised concerns that a US investor who bought a share on a non-US exchange in a company with a US subsidiary would not be protected from fraud conceived and committed at that subsidiary. ${ }^{28}$

In a September 2011 ruling in In re UBS Securities Litigation, Judge Richard Sullivan of the Southern District of New York cited Morrison in dismissing claims brought by all Plaintiffs who purchased stock on foreign exchanges. ${ }^{29}$ Judge Sullivan first rejected Plaintiffs' interpretation of Morrison that Section 10(b) applies to all purchases of securities registered with a US exchange, even purchases made abroad, and dismissed.all $\mathrm{F}^{3}$ claims ${ }^{30} \mathrm{He}$ further rejected plaintiffs' argument that purchases by investors who were located in the US, but whose purchase was executed on a foreign exchange, constituted domestic purchases for the purposes of Section 10(b) and dismissed the claims of such "f-squared" plaintiffs. ${ }^{31}$

\section{Potential impact of Morrison on US Markets}

By limiting which securities purchasers can participate in US shareholder class action litigation, the Morrison decision may improve the competitiveness of US public equity

27 Morrison at 2884.

28 Id. at 2895 (Stevens, J., dissenting).

29 In re UBS Sec. Litig., No. 07 Civ. 11225(RJS), 2011 WL 4059356 (S.D.N.Y. Sept. 13, 2011).

30 Id.

31 Id. 
markets. Not only does it make listing in the US more attractive, by reducing expected litigation costs, but it is likely to induce more trading in cross-listed stocks to be executed in the US. Class action litigation costs have been a frequently cited problem in the discussion about the competitiveness of US public equity markets following Sarbanes-Oxley Act of 2002 $(" S O X ") .{ }^{32}$

Morrison slashes the expected litigation exposure of any foreign issuer whose stock trades in the US to the percentage of its shares purchased in the US, by excluding investors who purchased overseas from classes. Consider a stock cross-listed in the US and the company's home country, with exactly $50 \%$ of trading done in each market. For simplicity, assume that, during the alleged class period, common stock is the company's only traded security, trading volume was identical in both markets on every day and that prices are always exactly equal at all times, controlling for exchange rates. ${ }^{33}$ Morrison halves the company's expected litigation exposure to only those shares purchased in the US. By reducing expected litigation costs, including associated costs of Directors and Officers insurance (D\&O insurance), Morrison improves the attractiveness of cross-listing in the US and therefore improves US competitiveness in attracting new listings. ${ }^{34}$

Morrison also improves the competitiveness of the US as a trading venue for cross-listed stocks and should attract a larger share of their volume to US markets. Morrison creates incentives

32 See, for example, the Interim Report of the Committee on Capital Markets Regulation, November 30, 2006, pp. $5,71-92$.

33 If the US share of volume varies from day to day and prices differ between the US and other markets, the proportion of damages due to US purchases will not exactly equal the US volume share.

34 This assumes that, consistent with historical evidence, before Morrison there was a minimal likelihood that a foreign company would be the subject of a 10b-5 suit if its securities did not trade in the US. 
for investors to execute their purchases in the US, precisely in order to be eligible to participate in shareholder class actions and be compensated via settlement distributions or damage awards. Academic research on where cross-listed stocks trade indicates that the demand for US execution is elastic and affected by the relative strength of investor protections in the US versus the home market. ${ }^{35}$ Therefore, it is probable that volume in cross-listed stocks will shift to the US.

The competitiveness gains for US listings and US trading execution are, however, offsetting. Increases in the US share of trading volume in cross-listed stocks will mitigate the expected litigation cost improvement from Morrison. If the US-executed share of volume in the stock discussed above rises from $50 \%$ to $60 \%$, the expected litigation cost savings associated with Morrison will fall from $50 \%$ to $40 \%$ savings.

\section{A. US competitiveness for global IPOs}

The costs of compliance with SOX were widely blamed for a decline in the US share in global IPOs, or public equity offerings by foreign issuers on exchanges outside their home countries. Since the financial crisis, the debate has shifted to the competitiveness effects of Dodd-Frank.

The US share of global initial offerings has declined by any measure, whether from its peak in 2000 or from the late 1990s. US initial public offerings ("IPOs") by foreign companies have declined as a percentage of global IPOs, defined as all IPOs by foreign companies outside of their home country, whether measured in number of IPOs or their value. After peaking at $82 \%$

35 Halling et al., "Where is the Market? Evidence from Cross-listings in the United States," Review of Financial Studies, 2008. 
of value and $54 \%$ in number in 2000, during the technology bubble, the US share of global IPOs fell to a low of $3 \%$ of value and $9 \%$ in number in 2008, before recovering somewhat. But even comparing 1996-1998 to 2009-2011, the US share of global IPOs remains greatly diminished. As shown in the graph below, in 1996-1998, the US was capturing an average of $72 \%$ of global IPOs by value, but that share was only $27 \%$ on average in $2009-1 \mathrm{H} 2011$. In number, the US share of global IPOs has declined somewhat less steeply, from 52\% in 19961998 to $24 \%$ in $2009-1 \mathrm{H} 2011$, but only because the US's share in the largest IPOs has declined faster than its share of all IPOs.

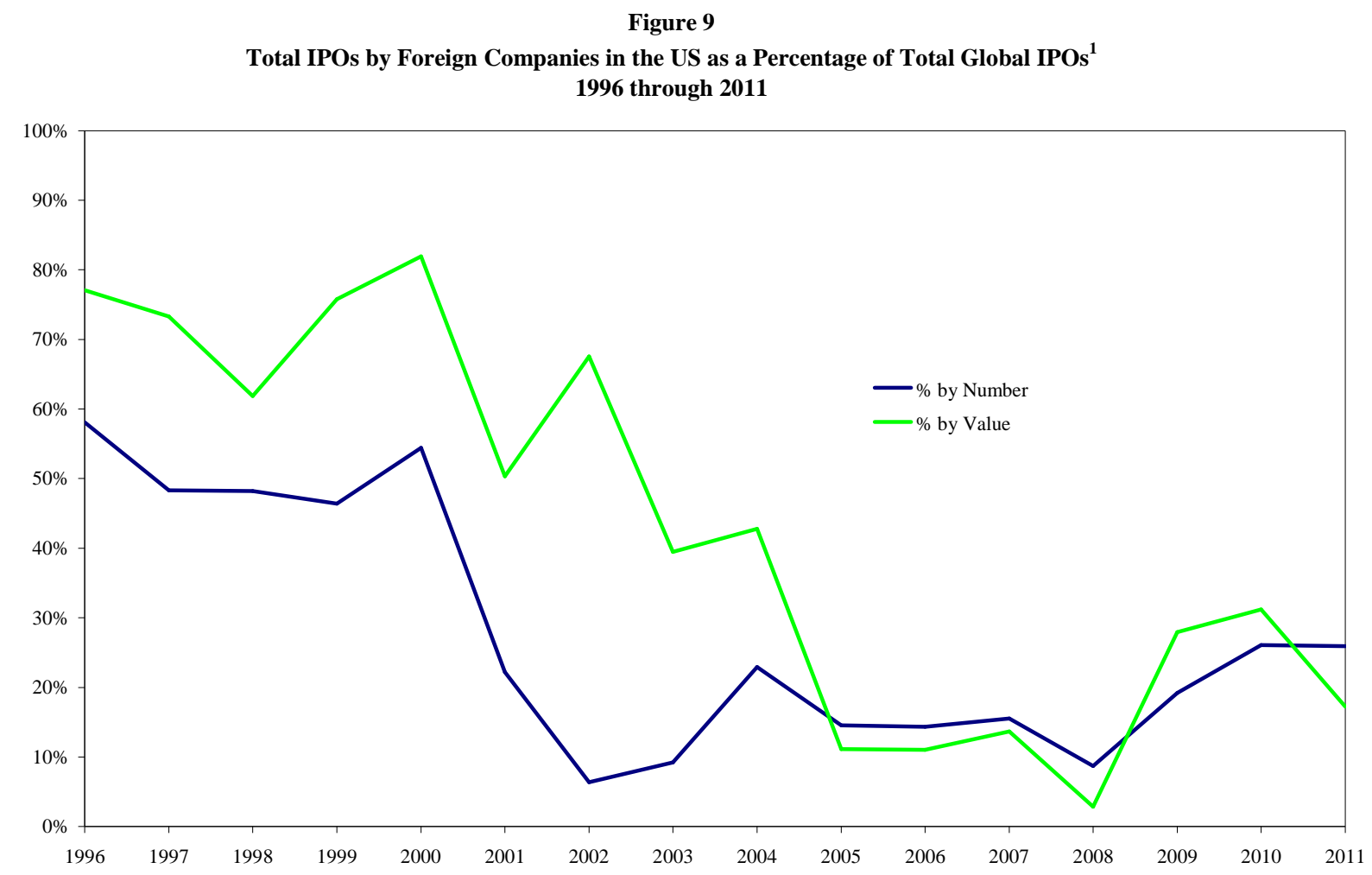

In addition to losing global IPOs to markets in other countries, the US public equity markets have lost market share to US 144A private placements. As a share of all global initial 
offerings, public or 144A, the US still attracts $53 \%$ in number and $46 \%$ in value, as shown in Figure 9.

Figure 10

Total Initial Offerings ${ }^{1}$ by Foreign Companies in the US as a Percentage of Total Global Initial Offerings 1996 through 2011

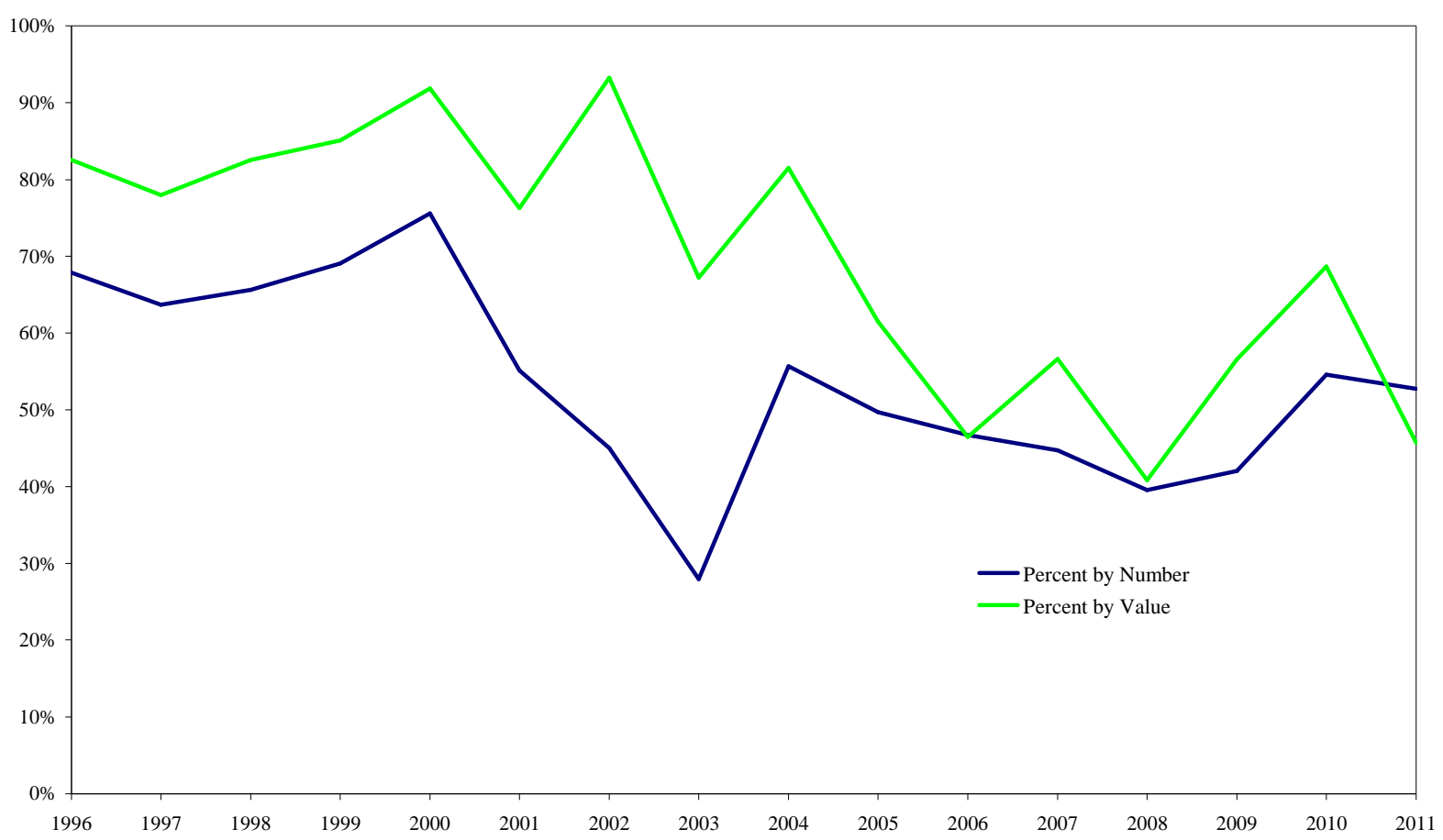

However, foreign issuers are now overwhelmingly raising equity in the US by 144A private placements, rather than by public offerings. IPOs accounted for $75 \%$ of all initial offerings by foreign issuers in 1996-1998, but only $23 \%$ in 2009-1H2011. 
Figure 11

Value of Foreign Offerings in US Markets 1996 through 2011

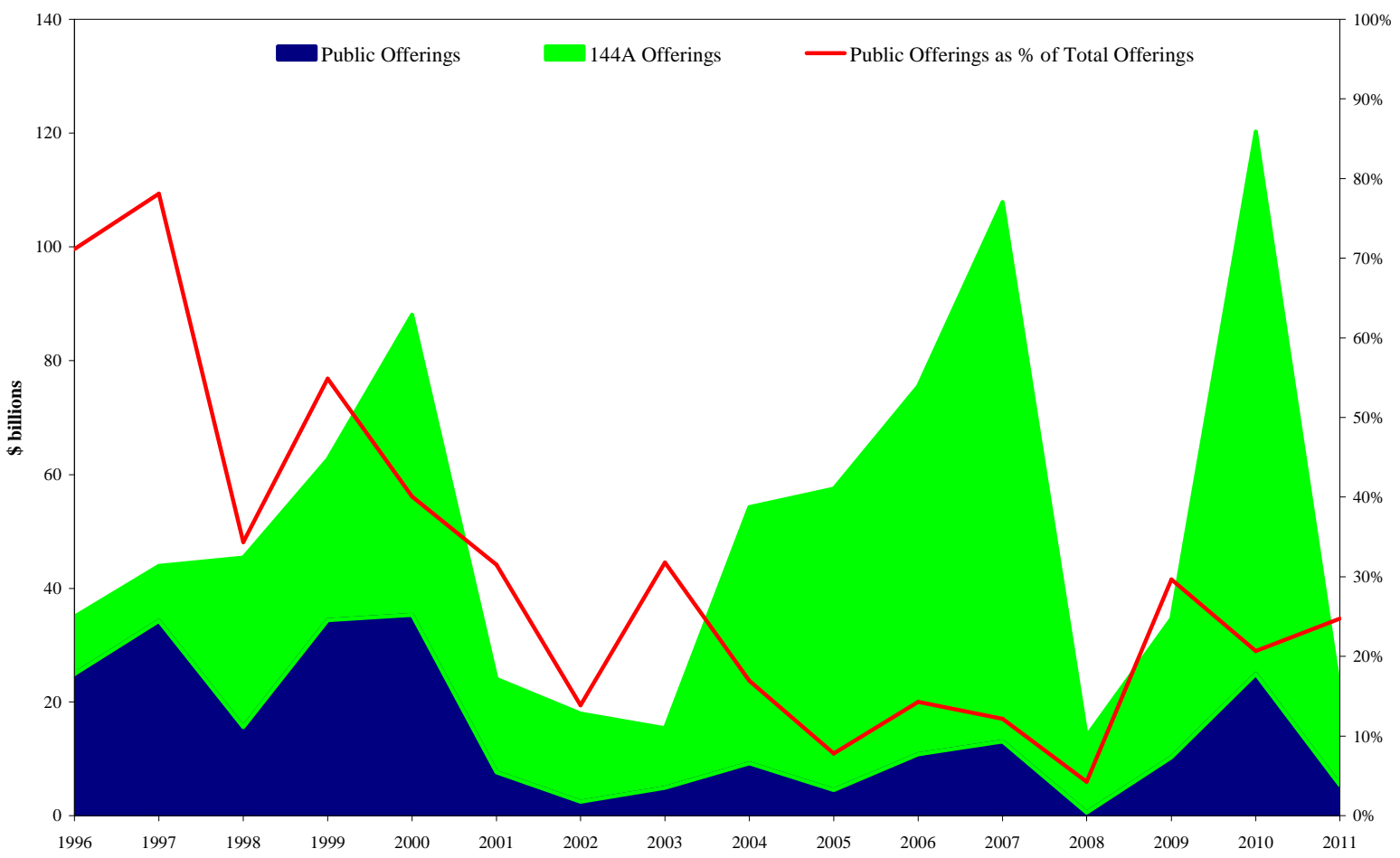

By electing to do a private placement, foreign companies can access US capital markets while avoiding the compliance costs associated with being a public company subject to SOX.

Furthermore, Rule 144A securities reduce potential litigation exposure. A company that does a private placement under Rule 144A is not subject to the Exchange Act of 1933 and therefore does not risk Section 11 or 12 actions. ${ }^{36}$ While that same company would be subject to Rule 10b-5, a 10b-5 class composed entirely of holders of Rule 144A securities is unlikely to be certified, or even brought, because the defense would almost certainly be able to demonstrate

36 Interim Report of the Committee on Capital Markets Regulation, November 30, 2006, p. 5, 
that the market was not efficient. However, with a 144A offering, a company can raise capital only from institutional investors. ${ }^{37}$

Foreign issuers face mixed incentives to list in the US. In terms of benefits, the US is an attractive venue to investors, because a US exchange listing carries with it substantial protections for minority investors. A US listed foreign company has met some standard of transparency by fulfilling US disclosure requirements and has voluntarily subjected itself to the US securities laws and SEC enforcement, therefore signaling a high standard of corporate governance and management conduct. ${ }^{38}$ A US listing provides improved access to US and international capital, thereby increasing the listing company's ability to finance investment opportunities. The benefits of a US listing include:

- Access to the US's liquid, orderly, efficient equity markets. Studies find a sustained and statistically significant reduction in cost of equity capital from US listing ${ }^{39}$

- Meeting US disclosure and reporting requirements improves transparency

- Access to capital of investors who prefer to invest in the US due to the protections and deterrent effect of US enforcement and private action. Such investors can (and do) opt to trade cross-listed stocks in US market. ${ }^{40}$

37 Fabozzi, Frank, The Handbook of Fixed Income Securities, Seventh Edition, McGraw Hill, 2005, p. 39.

38 This has been termed the "bonding" theory. See, for example, Karolyi, G.A., "The World of Cross-Listings and Cross-Listings of the World: Challenging Conventional Wisdom," Review of Finance (2006) 10, pp. 116121Doidge, C., Karolyi, G.A. and Stulz, R., "Has New York become less competitive than London in global markets?" Journal of Financial Economics 91 (2009), p. 4.

39 See, for example, Hail, L. and C. Leuz, "Cost of capital effects and changes in growth expectations around US cross-listings,” Journal of Financial Economics 93(2009), 428-454; Doidge, C., Karolyi, G.A. and Stulz, R., "Has New York become less competitive than London in global markets?" Journal of Financial Economics 91 (2009). 
However, companies also incur multiple costs when they list on US public markets:

- Regulatory and compliance costs

- Potential costs due to becoming subject to US enforcement action

- Directors and Officers (D\&O) liability insurance

- Potential class action litigation costs: $24.3 \%$ probability of suit in 5 years. ${ }^{41}$

However, these benefits are not all exclusive to the US. Some of these benefits are also available from listing in other host markets, such as gaining access to international investors. ${ }^{42}$

Those foreign issuers who access US markets via over-the-counter trading obtain lesser benefits, and incur lower costs. Because they trade on the OTC Bulletin Board or on pink sheets, they do not enjoy the same liquidity as exchange-traded securities. ${ }^{43}$ Class action litigation risk is lower, because these markets are unlikely to be found efficient, making cases against issuers whose stocks trade OTC unlikely to survive class certification. As a result, a foreign issuer whose stock trades OTC in the US faces lower odds of a class action filing, and the company's D\&O insurance costs presumably reflect this lower risk. Some foreign issuers access the US OTC markets by issuing Level 1 ADRs, so that they are required to make only

40 Halling et al., "Where is the Market? Evidence from Cross-listings in the United States," Review of Financial Studies, 2008, pp. 746, 747, 751, 754, and 755.

41 Calculated using NERA Securities Class Action database.

42 Fewer empirical studies measure the cost of capital benefits from cross listings in non-US markets and those are less conclusive. See Olga Dodd, "Price, Liquidity, Volatility and Volume of Cross-Listed Stocks," Durham University Ph.D. Thesis, 2011, p. 16.

43 Karolyi, G.A., "The World of Cross-Listings and Cross Listings of the World: Challenging Conventional Wisdom," Review of Finance 10 (2006), p. 101. 
minimal SEC disclosure and minimal GAAP compliance, reducing both the costs and benefits of transparency. ${ }^{44}$

Private placements offer companies access to US investors without the disclosure or compliance requirements, reporting costs or class action litigation risk associated with listing on a US exchange. However, the private placement market lacks the efficiency of the public markets with limited price transparency, wider bid-ask spreads, and a higher cost of capital, which in turn may deter capital formation. Hail and Leuz (2009) estimated that foreign issuers face a $2.38 \%$ higher cost of capital in the 144A market than if they cross-list on a US exchange. $^{45}$ Moreover, while they find that foreign issuers' cost of capital falls by between 70 and 120 basis points when they list on a US exchange, private placements have statistically insignificant effects, but in some regressions increase the issuer's cost of capital. ${ }^{46}$

While the declining US share of global IPOs and cross-listings has frequently been attributed to the costs of compliance with SOX, recent research concludes that the US remains a competitive market for cross-listing and that those firms opting for private placements or cross-listings in London generally do not have sufficient growth prospects to capture the benefits from a US

${ }^{44}$ Karolyi, G.A., "Why Do Companies List Shares Abroad?: A Survey of the Evidence and Its Managerial Implications" Financial Markets, Institutions and Instruments 7 (1998), p. 5.

45 Hail, L. and C. Leuz, "Cost of capital effects and changes in growth expectations around U.S. cross-listings," Journal of Financial Economics 93 (2009), p. 429. They find that OTC ADR listings also reduce cost of capital by between 30 and 70 basis points, but that this effect is not always statistically significant. OTC crosslistings require lesser disclosure than exchange listings. Exchange listings require SEC registration, extensive disclosure in filing Form 20-F, and financial statements reconciled to Generally Accepted Accounting Principles (GAAP); they also make the firm subject to SEC oversight and securities litigation, including class actions under Rule 10b-5. OTC listings involve lesser disclosure, but still make the company subject to SEC enforcement and Rule 10b-5 class actions. Private placements, however, require no SEC registration nor disclosures.

$46 \quad I d$. 
listing. ${ }^{47}$ Doidge, Karolyi and Stulz (2009) find that, controlling for firm characteristics, US exchanges retained their share of listings from 1990-2005 and that other cross-listing venues, US and overseas, have attracted firms with different characteristics. ${ }^{48}$ The authors argue that in an increasingly global financial market, governance benefits dominate access to international capital as the primary benefit from cross-listing, and that different kinds of cross-listings are distinguished by the governance benefits they offer. ${ }^{49}$ Firms that cross-list on US exchanges subject themselves to the US minority investor protection regime and commit to better governance because controlling shareholders will benefit more from the growth opportunities permitted by cross-listing than from the private benefits those shareholders must forego. Therefore, companies cross-listed on US exchanges are worth more both because of their better governance and their better growth opportunities. ${ }^{50}$ The authors find a statistically significant valuation premium associated with a US exchange listing in every year from 1990 to 2005, whereas initiation of US OTC trading is consistent with a smaller premium that is statistically significant in all but one year (2002) from 1993 to 2005. Neither 144A private placements or UK ordinary listings yield a statistically significant premium. ${ }^{51}$

Karolyi et al. (2009) further observe that the growth in UK listings is primarily due to listings on AIM, an exchange launched in 1995 to allow smaller firms that would not be eligible to list

47 Doidge, C., Karolyi, G.A. and Stulz, R., "Has New York become less competitive than London in global markets?" Journal of Financial Economics 91 (2009).

48 Id.

49 Id., p. 254.

$50 I d .$, p. 255.

${ }^{51} I d ., 269-273$. 
on a major US exchange to list with few disclosure or compliance requirements. ${ }^{52}$ Excluding AIM, the ratio of US to UK listings rose from $29 \%$ in 1992 to $165 \%$ in $2005{ }^{53}$ Firms that issue on the US Rule 144A and London Stock Exchange Depository Receipts markets are larger than those that list on US exchanges or as UK ordinary shares, but have higher proportions of closely held shares and are more likely to come from countries with lesser legal protections of minority shareholders. ${ }^{54}$

\section{B. Morrison reduces the litigation cost deterrent to cross-listing}

Companies considering a US listing must nonetheless weigh both the cost of capital savings they would enjoy against the additional regulatory and potential litigation costs they would incur. $^{55,56}$ In 2010, total shareholder class action settlement costs totaled $\$ 4.3$ billion. ${ }^{57}$ As

Figure 11 shows, although the average settlement dropped to $\$ 23$ million in the first half of 2011, they topped \$40 million in both 2009 and 2010, even when settlements over \$1 billion are excluded. ${ }^{58}$ Beyond settlement costs, defendants in major shareholder class actions also face legal costs, consultant fees and document production costs that can total millions of dollars and consume management attention. Follow-on litigation and regulatory actions can also result

52 Id., p. 255, 257.

53 Id., p. 256.

54 Id., p. 263.

55 They may also weigh other considerations, such as any private benefits that controlling shareholders would forego following a US listing.

56 Foley \& Lardner LLP conducted an annual survey of the total cost of being a US public company from 2001 through 2006, and found the 2006 average cost to be $\$ 2.8$ million. Foley \& Lardner LLP, "The Cost of Being Public in the Era of Sarbanes-Oxley," August 2, 2007.

57 Excluding settlements over \$1 billion. Calculated using NERA Securities Class Action database.

58 Milev, Jordan, Robert Patton and Svetlana Starykh, "Recent Trends in Securities Class Action Litigation: 2011 Mid-Year Review," NERA white paper, 26 July 2011, p. 22. 
because these cases often attract the scrutiny of the U.S. Department of Justice, SEC, and other regulators and may be followed by derivative or ERISA lawsuits, further escalating legal costs and demands on management.

Figure 12

Securities Class Actions: Average Settlement Value (\$MM)

January 2006 - June 2011

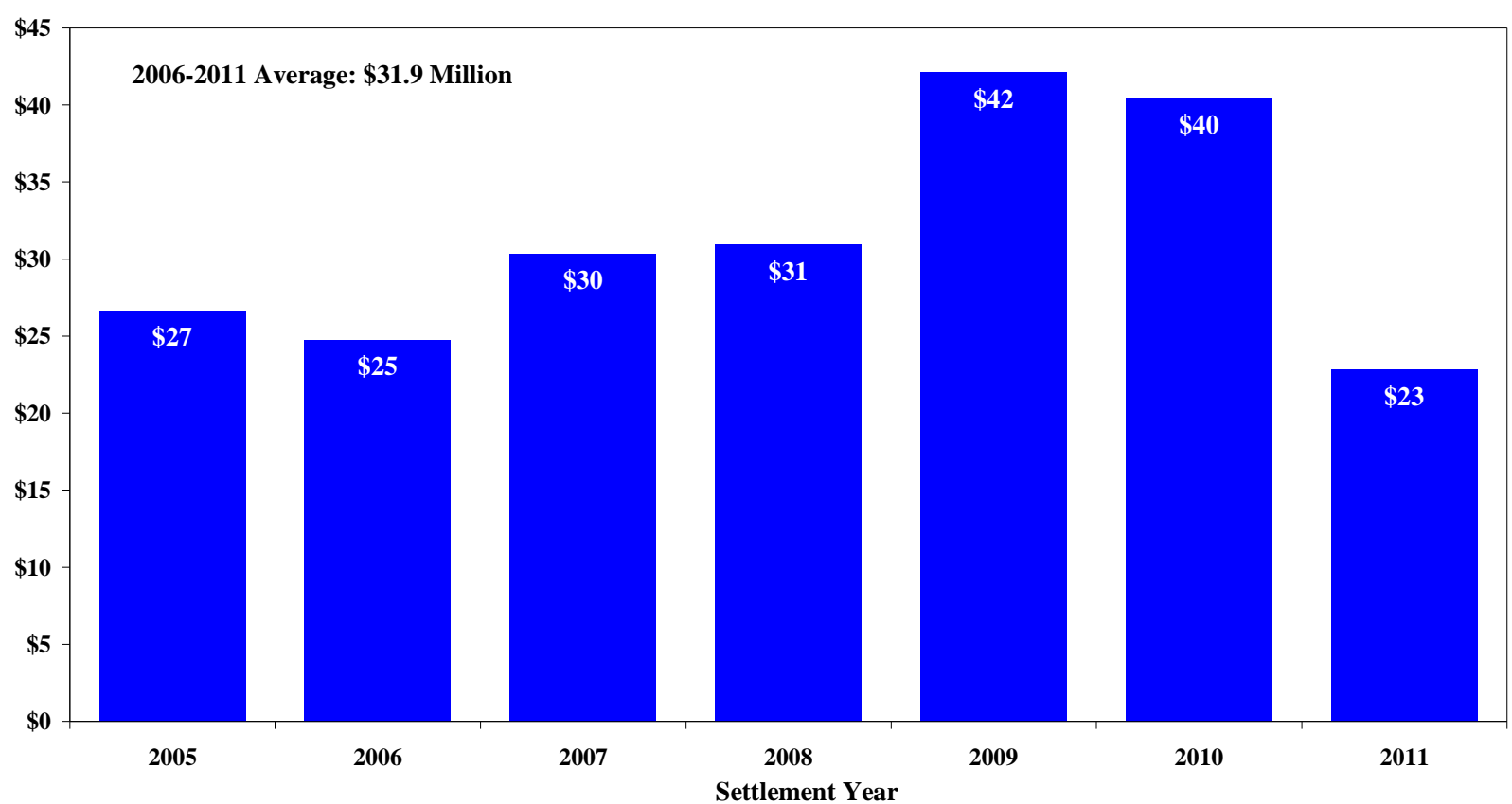

Note: Excludes settlements over $\$ 1$ billion and 309 settlements in IPO litigation

Prior to Morrison, foreign companies listed in the US faced an expected annual average class action litigation settlement cost of approximately $\$ 940,000$. This is calculated based on the 2.7\% January 2006 through June 2010 average probability of a foreign issuer facing a shareholder class action filing, times the $63.1 \%$ probability of class actions resulting in a settlement, ${ }^{59}$ times the January 2006 through June 2010 average foreign issuer settlement of

59 Milev et al., p. 14. Based on 2001 filings, the last year for which $100 \%$ of cases have been resolved, $36.9 \%$ by dismissal and $63.1 \%$ by settlement. 
$\$ 55.2$ million. $^{60}$ Moreover, foreign issuers have not been immune to large settlements. Figure 12 reports the distribution of settlement values for cases involving foreign issuers since January 1996. While the majority of cases settled for under $\$ 10$ million, $23 \%$ of cases settled for more than $\$ 50$ million. The top 10 settlements with foreign issuers are all at least $\$ 75$ million, with three in excess of $\$ 1$ billion. ${ }^{61}$

Figure 13

Distribution of Settlement Values with Foreign Companies Listed in the US (\$MM)

January 1996 - June 2011

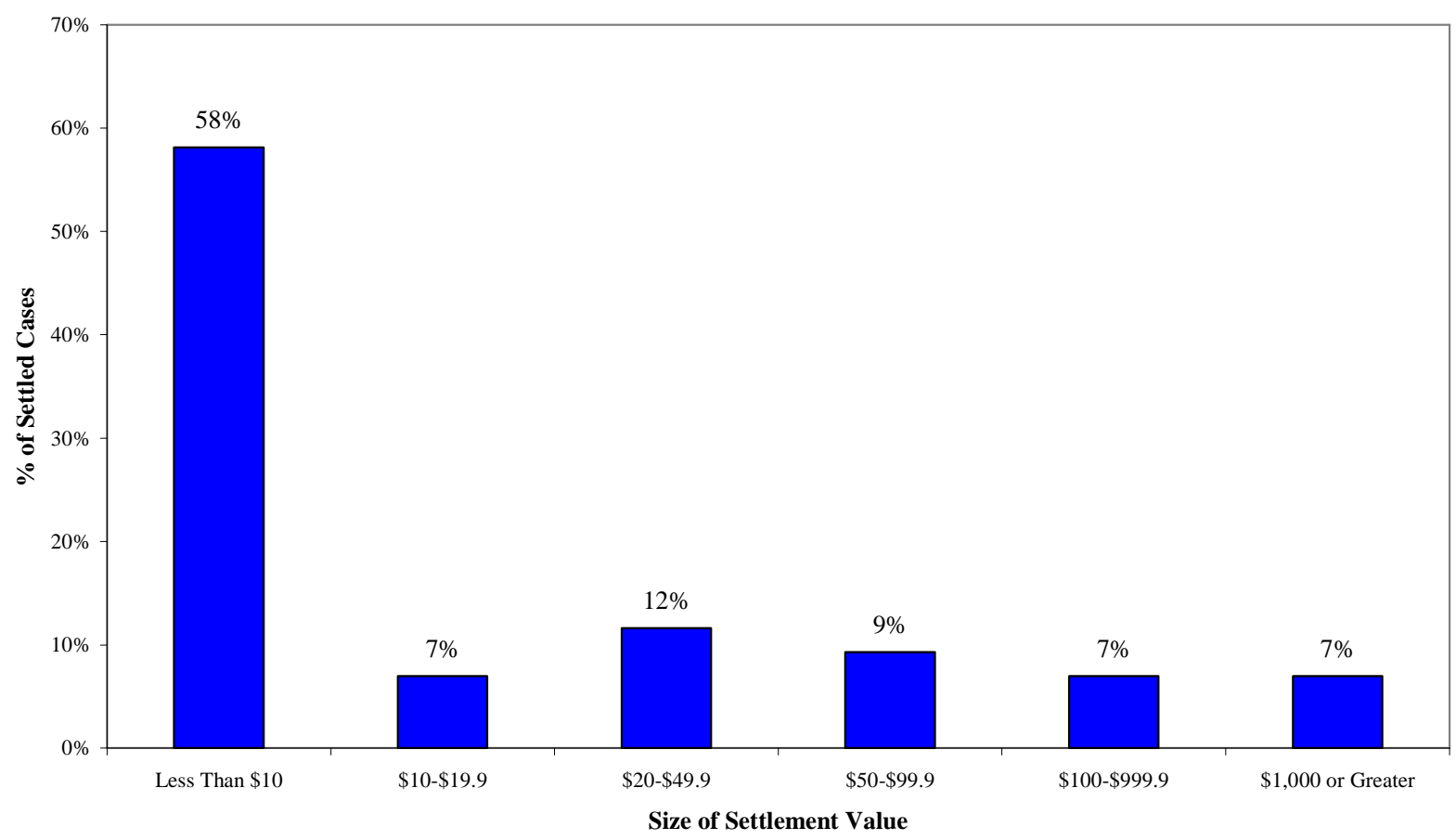

Following Morrison, foreign companies' expected litigation costs should fall, as overseas purchases are excluded from classes, driving down damages and settlements. Had the top three foreign issuer settlements taken place after Morrison, all should have been much smaller. In

60 While D\&O insurance may substantially cover a company's settlement and associated legal fees, companies need to purchase $\mathrm{D} \& \mathrm{O}$ insurance at rates that reflect these risks.

61 NERA Securities Class Action database. 
the two Nortel cases, $65.3 \%$ and $50.8 \%$ of class period trading volume, respectively, occurred in the US. In the Royal Ahold case, only $2.4 \%$ of trading occurred in the US. All three settlements included all $\mathrm{F}^{3}$ investors. Had the settlements been reduced proportionally to the percentage of volume traded outside the US, the two Nortel settlements would have fallen from $\$ 1.14$ and $\$ 1.07$ billion to $\$ 744$ million and $\$ 544$ million, respectively, and the $\$ 1.10$ billion Royal Ahold settlement would have fallen to \$26 million.

Table 1

Top Ten Shareholder Class Action Settlements against Non-US Companies

\begin{tabular}{|c|c|c|c|c|}
\hline Ranking & Company & $\begin{array}{c}\text { Settlement } \\
\text { Year } \\
\end{array}$ & $\begin{array}{c}\text { Total } \\
\text { Settlement } \\
\text { Value } \\
(\$ M M) \\
\end{array}$ & Country \\
\hline (1) & (2) & (3) & (4) & (5) \\
\hline 1 & Nortel Networks (I) & 2006 & 1,143 & Canada \\
\hline 2 & Royal Ahold, NV & 2006 & 1,100 & Netherlands \\
\hline 3 & Nortel Networks (II) & 2006 & 1,074 & Canada \\
\hline 4 & DaimlerChrysler AG/Chrysler Corporation & 2003 & 300 & Germany \\
\hline 5 & Sumitomo (Copper Trading) Corp. & 2001 & 149 & Japan \\
\hline 6 & Biovail Corp. (S.D.N.Y.) & 2008 & 138 & Canada \\
\hline 7 & Deutsche Telekom AG & 2005 & 120 & Germany \\
\hline 8 & Royal Dutch Petroleum Company/Shell Transport and Trading Co. & 2008 & 90 & Netherland \\
\hline 9 & Converium Holding AG (2004) & 2008 & 85 & Switzerland \\
\hline 10 & Elan Corp. P.L.C. & 2004 & 75 & Ireland \\
\hline & Total & & 4,273 & \\
\hline
\end{tabular}

Foreign issuers' expected class action litigation cost could fall even further if the exclusion of foreign volume from classes discourages some filings or reduces the aggressiveness with which plaintiffs' counsel litigates them. If so, this would further reduce the litigation cost deterrent to cross-listing in the US. If only shares purchased in the US are included in a class, alleged 
damages will drop by the percentage of overseas volume, ${ }^{62}$ bringing down settlements and awards to plaintiff's counsel as legal fees. Courts typically award fees to plaintiffs counsel as a decreasing percentage of settlement size, where median fees in the first half of 2011 were $25 \%$ of settlement. ${ }^{63}$ Therefore, the financial incentive to the plaintiffs' bar to file and litigate cases against foreign issuers will fall. This may deter plaintiffs' counsel from filing some smaller cases, if the exclusion of foreign volume drives alleged damages below some minimum threshold value. ${ }^{64}$ Perhaps more importantly, by driving down the entire distribution of expected settlement sizes and expected fee awards, Morrison may also reduce the aggressiveness with which the plaintiffs' bar pursues foreign issuer complaints, further driving down foreign issuer settlements.

\section{Cross-listed stock volume may follow investor protections to the US}

The US also competes for trading volume of cross-listed stocks. US trading volume in ADRs was $22.0 \%$ of home market volume for those stocks in 2010, above the 2001-2006 average of 17.7\% ; since 2001, volume has been increasing. ${ }^{65}$ All these percentages, however, represent a

${ }^{62}$ For the purposes of this discussion, we maintain the simplifying assumption above that during the alleged class period, common stock is the company's only traded security, trading volume was identical in both markets on every day and that are always exactly equal at all times, controlling for exchange rates such that the proportion of damages due to US purchases will exactly equal the US volume share.

63 Milev et al., p. 28. Median fees were $33.3 \%$ on settlements of $\$ 5$ million or less, declining to $8.3 \%$ on settlements of $\$ 500$ million or more, based on January 1996 to June 2011 settlements.

64 This assumes that plaintiffs' counsel estimate damages prior to filing complaints.

65 Committee on Capital Markets Regulation using the Bank of New York Mellon International 100 ADR Index; see http://www.capmktsreg.org/competitiveness/2011Q2update/(12)ADR_Trading_Volumes_in_the_US.pdf. 
large drop from the US to home market volume ratio from 1980-2001, which Halling et al. estimated at $20-40 \%$ for developed countries and $80-450 \%$ for emerging markets. ${ }^{66}$

Halling et al. also analyzed both home market level determinants of the US volume ratio, as well as the stock-specific determinants more commonly studied in the literature on cross-listed stocks. They found that US volume was greater if the home country is close to the US, had underdeveloped markets, or had weak enforcement against insider trading. They also found that home volume reacted based on country characteristics. Home volume rose permanently following a US listing if the home country was developed, such that a US listing increased total volume. However, home volume fell if domestic enforcement against insider trading was weak, with volume shifting to the US. ${ }^{67}$ While their sample is dated, Halling et al.'s results signal that investors will direct trading volume to the market that offers better investor protection.

This potential for volume shifting suggests that investors may direct trades in cross-listed stocks to be executed in the US in order to be eligible to participate in class action litigation and benefit from settlements. Court decisions have already excluded from classes purchases made by US investors but executed outside the US. Following Morrison, Judge John G. Koetl of the Southern District of New York dismissed with prejudice a shareholder class action against Swiss Re because lead plaintiff Plumber's Local No. 12 Pension Fund's shares had been purchased on a foreign exchange, although the purchase order had been communicated in the

${ }^{66}$ Halling et al., "Where is the Market? Evidence from Cross-listings in the United States," Review of Financial Studies, 2008, p. 744.

67 Halling et al., "Where is the Market? Evidence from Cross-listings in the United States," Review of Financial Studies, 2008, pp. 742-755. 
US. $^{68}$ In Sgalambo vs. McKenzie, Judge Shira A. Scheindlin dismissed all claims involving purchases of Canadian Superior stock on the Toronto Stock Exchange. ${ }^{69}$

There have been conflicting opinions as to whether ADRs qualify as purchases in the US. Judge Richard Berman dismissed the entire class of In re Société Générale Securities Litigation on the grounds that even trades in the company's ADRs are primarily foreign securities transactions; the decision noted that these ADRs traded over the counter, as opposed to on a US exchange..$^{70,71}$ If other courts follow Société Générale, foreign issuers whose stocks trade only as over the counter ADRs in the US would be immune from shareholder class action litigation, similar to private placements. However, subsequently, in In re Elan Corporation Securities Litigation, Judge Alvin K. Hellerstein did not follow Société Générale, allowing the case to proceed for Elan's ADRs, which are exchange-traded. ${ }^{72}$

Going forward, at least some institutional investors are likely to request that their trades in cross-listed stocks be executed in the US, or at least discuss the relative merits of execution in the US versus other markets. Any resulting shift in volume to the US will enhance the volume and liquidity of US markets, and by enhancing liquidity, also promoting a lower cost of capital, which in turn make US markets more competitive.

68 Plumbers' Local Union No. 12 Pension Fund v. Swiss Reinsurance Co., 753 F. Supp. 2d 166 (S.D.N.Y. 2010$).$

69 Sgalambo v. McKenzie, 739 F. Supp. 2d 453 (S.D.N.Y. 2010).

70 In re Societe Generale Sec. Litig., No. 08 Civ. 2495 (S.D.N.Y. Sept. 29, 2010).

71 Prior to Morrison, the fact that Société Générale's ADRs traded over-the-counter, rather than on a US exchange, might have led defendants to challenge market efficiency at the class certification stage.

72 In re Elan Corp. Sec. Litig, Nos. 08 Civ. 8761, 10 Civ. 5630 (S.D.N.Y. March 18, 2011). 


\section{Conclusion}

Morrison eases a deterrent to US listing by foreign issuers by reducing expected litigation costs for cross-listed companies. Unless Congress legislates a new private right of action, Morrison may result in more foreign issuers cross-listing in the US as well as shifting of volume in crosslisted stock to the US. ${ }^{73}$ Both effects are favorable to the competitiveness of US markets.

73 Similarly, Morrison may result in a lower rate of delisting by foreign issuers with US listings. 


\section{BIBLIOGRAPHY}

\section{Articles}

American Bar Association, "Securities Class Actions in a Global Economy: Investor Claims Against Non-US Issuers," 2007, p. 10, 13.

Buschkin, Ilana, "The Viability of Class Action Lawsuits in a Globalized Economy Permitting Foreign Claimants to be Members of Class Actions Lawsuits in the U.S. Federal Courts," Cornell Law Review, Vol. 90, 2005.

Buxbaum, Hannah, "Multinational Class Actions Under Federal Securities Law:

Managing Jurisdictional Conflict," Columbia Journal of Transnational Law, Volume 46, Issue 1, June 2007, p. 21, 23, 42-3.

Dodd, Olga "Price, Liquidity, Volatility and Volume of Cross-Listed Stocks," Durham University Ph.D. Thesis, 2011, p. 16.

Doidge, C., Karolyi, G.A. and Stulz, R., "Has New York become less competitive than London in global markets?" Journal of Financial Economics 91 (2009).

Fabozzi, Frank, The Handbook of Fixed Income Securities, Seventh Edition, McGraw Hill, 2005, p. 39.

Foley \& Lardner LLP, "The Cost of Being Public in the Era of Sarbanes-Oxley," August 2, 2007.

Gagnon, Louis and Karolyi, G.A., "Information, Trading Volume, and International Stock Return Comovements : Evidence from Cross-Listed Stocks," Journal of Financial and Quantitative Analysis, Vol. 44, No. 4, 2009.

Gassman, Gary and Perry Granof, "Global Issues Affecting Securities Claims at the Beginning of the Twenty-First Century," Tort Trial \& Insurance Practice Law Journal, Fall 2007 (43:1), pp. 85-111. 
Grant, Stuart and Diane Zilka, "The Role of Foreign Investors in Federal Securities Class Actions," Securities Litigation and Enforcement Institute 2004, Corporate Law and Practice, Course Handbook Serieis Number B-1442.

Hail, L. and C. Leuz, "Cost of capital effects and changes in growth expecations around US cross-listings," Journal of Financial Economics 93(2009), 428-454.

Halling et al., "Where is the Market? Evidence from Cross-listings in the United States," Review of Financial Studies, 2008.

Interim Report of the Committee on Capital Markets Regulation, November 30, 2006, pp. 5, 71-92.

Karolyi, G.A., "The World of Cross-Listings and Cross-Listings of the World:

Challenging Conventional Wisdom," Review of Finance (2006) 10, pp. 101, 116-121.

Karolyi, G.A., "Why Do Companies List Shares Abroad?: A Survey of the Evidence and Its Managerial Implications" Financial Markets, Institutions and Instruments 7 (1998), p. 5 .

Milev, Jordan, Robert Patton and Svetlana Starykh, "Recent Trends in Securities Class Action Litigation: 2011 Mid-Year Review," NERA white paper, 26 July 2011, p. 14, $22,28$.

Pinna, Andrea, "Recognition and Res Judicata of US Class Action Judgments in European Legal Systems," Erasmus Law Review, Volume 1, Issue 2, 2007.

\section{Court Decisions and Filings}

Bersch v. Drexel Firestone, Inc., 519 F.2d 974, 996 (2d Cir. 1975).

Brief of Amici Curiae the Securities Industry and Financial Markets Association et al. in Support of Respondents at 4, Morrison v. National Australia Bank Ltd., 130 S. Ct. 2869 (2010) (No. 08-1191).

Brief for the United States as Amicus Curiae at 13, Morrison v. National Australia Bank Ltd., 130 S. Ct. 2869 (2010) (No. 08-1191).

In re Elan Corp. Sec. Litig, Nos. 08 Civ. 8761, 10 Civ. 5630 (S.D.N.Y. March 18, 2011).

In re Societe Generale Sec. Litig., No. 08 Civ. 2495 (S.D.N.Y. Sept. 29, 2010).

Morrison v. National Australia Bank Ltd., 130 S. Ct. 2869, 2874-75, 2878, 2884, 2895 (2010).

Morrison v. National Australia Bank Ltd., 547 F. 3d 167, 175 (2d Cir. 2008). 
Plumbers' Local Union No. 12 Pension Fund v. Swiss Reinsurance Co., 753 F. Supp. 2d 166 (S.D.N.Y. 2010).

Schoenbaum v. Firstbrook 405 F.2d 215 (2d. Cir. 1968) at 206.

Sgalambo v. McKenzie, 739 F. Supp. 2 d 453 (S.D.N.Y. 2010).

\section{Other Data Sources}

Committee on Capital Markets Regulation, Second Quarter 2011 Update:

http://www.capmktsreg.org/competitiveness/2011Q2update/(12)ADR_Trading_Volum es_in the US.pdf.

NERA Economic Consulting, Class Action Database. 